\title{
Prestasi Belajar ditinjau dari Kedisiplinan pada Siswa Perguruan Setia Budi Abadi Perbaungan
}

\section{Academic Achievement Based on Discipline Among the Students of PerguruanSetia Budi AbadiPerbuangan}

\author{
Jeslin*, Sarinah \& Achmad Irvan Dwi Putra \\ Program Studi Psikologi, Fakultas Psikologi, Universitas Prima Indonesia, Indonesia
}

Diterima: Mei 2019; Disetujui: Juli 2019; Dipublish: Agustus 2019

*Email: esssslin96@gmail.com

\begin{abstract}
Abstrak
Tujuan dari penelitian ini yaitu untuk mengetahui hubungan antara kedisiplinan dengan prestasi belajar. Hipotesis yang diajukan dalam penelitian ini adalah ada hubungan positif antara kedisiplinan dengan prestasi belajar. Subjek penelitian pada penelitian ini adalah siswa SMA kelas XI dan XII Perguruan Setia Budi Abadi Perbaungan sebanyak 123 orang. Data diperoleh dari hasil nilai rapor dari setiap subjek untuk mengukur prestasi belajar dan data dari skala untuk mengukur kedisiplinan. Teknik analisis data yang akan digunakan pada penelitian ini adalah teknik korelasi Spearman Rho melalui bantuan SPSS 20 for Windows. Hasil analisis data menunjukkan koefisien korelasi sebasar 0,688 $(\mathrm{p}<0,05)$. Ini membuktikan bahwa terdapat hubungan positif antara kedisiplinan dengan prestasi belajar. Berdasarkan hasil dari penelitian ini dapat disimpulkan bahwa terdapat hubungan positif antara kedisiplinan dengan prestasi belajar.
\end{abstract}

Kata Kunci: Kedisiplinan, Prestasi Belajar

Abstract
This study aims to determine the relationship between discipline and academic achievement. The hypothesis of this study states that there is a positive relationship between discipline and academic achievement. Subjects of this study were 123 students of Perguruan Setia Budi Abadi Perbaungan. Data were obtained from the school report card to measure academic achievement and data were obtained from a scale to measure discipline. Data were analyze by Spearman's Rank Order Correlation with SPSS 20 for Windows. The results of data analysis showed that the correlation coefficien was 0,688 $(p<0,05)$. It showed that there is a positive relationship between discipline and academic achievement. From these results it is concluded that the hypothesis stating there is a positive relationship between discipline and academic achievement is acceptable.

Keywords: Discipline, Academic Achievement

How To Cite: Jeslin, Sarinah \& Putra, A.I.D. (2019). Prestasi Belajar ditinjau dari Kedisiplinan pada Siswa Perguruan Setia Budi Abadi Perbuangan. Journal of Education, Humaniora and Social Sciences (JEHSS). 2 (1): 24-35.

\section{PENDAHULUAN}

Dewasa ini umat manusia berada di dalam transformasi sosial yang sangat cepat. Transformasi sosial telah melahirkan suatu dunia yang baru yaitu suatu dunia yang terbuka dengan berbagai aspek positif dan negatifnya. Dunia yang terbuka berarti dunia yang kompetitif. Apabila bangsa Indonesia dapat mempersiapkan diri sebaik-baiknya dalam memasuki era globalisasi, maka banyak manfaat yang dapat diambil dari dalamnya karena kita dipaksa untuk menjadi manusia yang terbaik yang bisa 
berkompetisi. Dunia yang semakin terbuka dapat memberikan kesempatan kepada kita untuk belajar lebih banyak dari pergaulan antarbangsa. Demikian pula sumbangan potensi manusia dan kekayaan alam Indonesia dapat dimanfaatkan bukan hanya untuk bangsa Indonesia tetapi juga bagi kesejahteraan umat manusia. Dalam hal ini peranan pendidikan nasional menjadi sangat mutlak (Tilaar, 2002).

Pendidikan merupakan sebuah upaya untuk memberikan pengetahuan, wawasan, keterampilan dan keahlian tertentu kepada individu agar dapat mengembangkan bakat dan kepribadian mereka (Triwiyanto, 2015). Pendidikan tidak hanya membuat individu menjadi pintar dan cerdas melainkan untuk membuat individu dapat menghargai nilainilai sosial yang timbul dan berkembang dalam masyarakat juga. Nilai-nilai yang dimaksud adalah nilai-nilai moral seperti nilai kekerabatan, kekeluargaan, saling menghargai dan menghormati (Seran, 2016).

Pendidikan di sekolah memiliki pengaruh yang sangat besar terhadap pembentukan kemampuan dan pengalaman manusia. Sekolah adalah sekelompok layanan pendidikan yang menyediakan pendidikan melalui jalur formal, nonformal dan informal pada setiap jenjang serta jenis pendidikan. Sekolah bertugas untuk menciptakan kondisi yang dapat mengembangkan pribadi anak secara optimal (Triwiyanto, 2015).

Untuk meningkatkan hasil belajar perlu dilihat kondisi eksternal dan internal. Kondisi internal adalah suatu situasi atau kondisi yang ada dalam diri siswa, seperti keterampilan, kemampuan, kesehatan dan sebagainya. Kondisi eksternal adalah suatu kondisi yang terdapat di luar diri siswa, seperti sarana dan prasarana belajar yang memadai, dan ruang belajar yang bersih. Pengetahuan, keterampilan, dan pengalaman yang didapat akan memperluas wawasan kehidupan, membentuk kepribadian siswa, serta mampu untuk meningkatkan kemampuan yang ada pada siswa. Akibat dari itu, maka siswa yang aktif dalam kegiatan pembelajaran akan mendapatkan banyak pengalaman. Sebaliknya, siswa yang tidak aktif akan sedikit pengalaman (Habsari, 2005).

Berdasarkan observasi yang dilakukan peneliti terhadap siswa kelas XI dan XII pada sekolah Perguruan Setia Budi Abadi Perbaungan, sering ditemukan siswa yang dengan sengaja membuat keributan di kelas seperti bercerita-cerita dan berteriak pada saat proses belajar mengajar sedang berlangsung. Ada juga siswa yang mengantuk dan tidak mencatat apa yang sedang dipelajari, siswa kurang antusias dalam belajar 
dikarenakan guru kurang menguasai kondisi kelas dan kurang mampu menciptakan interaksi belajar mengajar yang optimal. Hanya terdapat beberapa siswa yang aktif saat pembelajaran, sedangkan siswa yang lainnya tidak akan bertanya apabila tidak ditanya oleh guru. Guru menyatakan bahwa mereka sudah melakukan berbagai variasi teknik mengajar yang baik, namun dalam pencapaian hasil belajar siswa masih tergolong rendah. Hal ini terbukti dari nilai harian maupun ulangan semester yang jauh dari kategori lulus. Siswa dikatakan lulus apabila mencapai KKM 78, dalam kenyataannya persentasi kelulusan hanya sekitar 55\%.

Selain itu, beban materi yang banyak dengan alokasi waktu terbatas, menyebabkan guru kurang berinovasi mengembangkan model pembelajaran. Dampaknya adalah kemampuan siswa membangun konsep kurang, memori jangka panjang rendah, hasil belajar siswa tidak maksimal. Banyaknya materi yang harus dipelajari menuntut kemampuan memori dalam mengingat, yang dapat beresiko terjadinya kelupaan. Sedangkan $80 \%$ dari apa yang kita pelajari akan terlupakan hanya dalam jangka waktu 24 jam. Untuk mencegah hal tersebut maka diperlukan untuk belajar secara bertahap dan berulang-ulang agar siswa lebih mampu untuk memahami pelajaran yang diajarkan.

Kasus-kasus diatas menunjukkan bahwa berbagai masalah dapat timbul dalam kegiatan belajar, seperti bagaimana cara untuk menciptakan kondisi yang baik supaya berhasil, membuat rencana belajar bagi siswa, memilih metode yang sesuai dengan situasi dan jenis belajar, penilaian hasil belajar,menyesuaikan proses belajar dengan kemampuan yang dimiliki oleh siswa, mengdiagnosis penyebab kesulitan belajar, dan sebagainya. Bagi siswa, ada beberapa masalah-masalah belajar yang dapat timbul seperti memilih cara belajar, pengaturan waktu belajar, belajar kelompok, menggunakan bukubuku pelajaran, memilih mata pelajaran yang cocok, mempersiapkan ujian, dan sebagainya. (Yusuf dan Nurihsan, 2008) Keberhasilan dari setiap proses belajar mengajar diukur dari seberapa jauh hasil belajar yang dicapai siswa atau yang disebut juga dengan prestasi belajar (Jihad dan Haris, 2013).

Menurut Tu'u (dalam Kusuma dan Subkhan, 2015), prestasi belajar adalah kemampuan untuk menguasai pengetahuan atau keterampilan yang dikembangkan oleh mata pelajaran, yang ditunjukkan dengan nilai ulangan atau nilai tes yang diberikan oleh guru. Namun prestasi belajar menurut Ahmadi (dalam Habsari, 2005) adalah hasil yang 
dapat dicapai dalam sebuah usaha (belajar) untuk menciptakan perubahan atau mencapai tujuan.

Menurut Surya dan Barlow (dalam Syah, 2015), aspek-aspek dari prestasi belajar yaitu, (1) Ranah Cipta (Kognitif) yang terdiri dari pengamatan, ingatan, pemahaman, analisis (pemeriksaan dan penilaian secara teliti), aplikasi atau penerapan, dan sintesis (membuat panduan baru dan utuh); (2) Ranah Rasa (Afektif) yang terdiri dari penerimaan, sambutan, spresiasi (sikap menghargai), internalisasi (pendalaman), dan karakterisasi (penghayatan); (3) Ranah Karsa (Psikomotor) yang terdiri dari keterampilan bergerak dan bertindak, serta kecapakan ekspresi verbal dan non-verbal.

Terdapat beberapa faktor yang dapat mempengaruhi prestasi belajar yang dikategorikan menjadi dua kelompok, yaitu internal dan eksternal. Salah satu faktor internal adalah disiplin belajar (Sumantri, 2010). Hal itu terbukti dari penelitian yang dilakukan oleh Kusuma dan Subkhan (2015) yang menyatakan bahwa disiplin belajar berpengaruh positif dan signifikan terhadap prestasi belajar akuntansi. Semakin tinggi disiplin belajar siswa maka prestasi belajar akuntansi siswa akan semakin tinggi pula. Sebaliknya, semakin rendah disiplin belajar siswa maka prestasi belajar akuntansi siswa akan semakin rendah.

Menurut Mulyasa (dalam Kusuma dan Subkhan, 2015) disiplin adalah suatu keadaan dimana orang yang bergabung dalam suatu organisasi tunduk pada peraturan yang sudah ada dengan rasa senang hati. Hurlock (2006) menerangkan bahwa disiplin adalah suatu proses dari latihan atau belajar yang berhubungan dengan pertumbuhan dan perkembangan. Seseorang dapat dikatakan sudah berhasil dalam mempelajari apabila ia dapat mengikuti tokoh-tokoh yang telah mengajarkan sesuatu kepadanya, yaitu orang tua atau guru-guru.

Menurut Atmosudirdjo (dalam Offirstson, 2014), disiplin memiliki 3 (tiga) aspek. Ketiga aspek tersebut yaitu, (1) Suatu sikap mental (mental attitude, state of mind) yang merupakan sikap yang taat serta tertib sebagai hasil dari latihan dan pengendalian pikiran, serta watak oleh pemimpin secara tertentu; (2) Suatu pengetahuan (knowledge) tentang aturan-aturan dalam berperilaku, sistem atau norma-norma, kriteria, dan standar-standar sedemikan rupa sehingga pengetahuan tersebut dapat menumbuhkan pengertian bahwa ketaatan akan aturan-aturan, norma-norma, kriteria, dan standarstandar tadi merupakan syarat yang mutlak dalam mencapai keberhasilan; (3) Suatu 
sikap kelakuan (behavior) yang menunjukkan pengertian dan kesadaran, kesungguhan hati, dalam mentaati segala hal dengan cermat dan tertib.

Berdasarkan hasil kajian literatur yang ada, Terdapat beberapa peneliti dan ahli yang telah melakukan penelitian untuk menunjukkan bahwa kedisiplinan mempengaruhi prestasi belajar. Salah satunya adalah penelitian yang dilakukan oleh Puspitasari dan Sutriyono (2017) terhadap 60 peserta didik kelas VII di SMP Kristen 1 Klaten, menunjukkan adanya hubungan yang signifikan antara kedisiplinan belajar dengan prestasi belajar.

Selain kedisiplinan, terdapat faktor lain yang juga mempengaruhi prestasi belajar. Penelitian yang dilakukan oleh Rusmiati (2017) terhadap 130 siswa Madrasah Aliyah Al Fattah Sumbermulyo menunjukkan bahwa adanya hubungan positif antara minat belajar dengan prestasi belajar pada bidang studi ekonomi siswa Madrasah Aliyah Al Fattah Sumbermulyo. Faktor lain yang bisa mempengaruhi prestasi belajar adalah konsep diri siswa. Hal ini terbukti dari penelitian yang dilakukan oleh Liauwrencia \& Putra (2014) terhadap 32 siswa SMA Dharma Putra Tangerang yang menunjukkan bahwa konsep diri dapat mempengaruhi prestasi belajar siswa. Hasil penelitian ini menyatakan bahwa terdapat hubungan yang positif antara konsep diri siswa dengan prestasi belajar siswa.

Berdasarkan dari semua uraian diatas, peneliti sangat tertarik dalam melakukan penelitian untuk mengetahui hubungan kedisiplinan dengan prestasi belajar pada siswa SMA kelas XI dan XII Perguruan Setia Budi Abadi Perbaungan. Adapun hipotesis yang dapat diajukan dalam penelitian ini adalah "Adanya hubungan positif antara kedisiplinan dengan prestasi belajar", yang artinya semakin tinggi kedisiplinan maka semakin tinggi juga prestasi belajarnya, sebaliknya jika semakin rendah kedisiplinan maka semakin rendah juga prestasi belajarnya. Manfaat dari penelitian ini yaitu untuk memberikan masukan atau gambaran yang bermanfaat bagi siswa untuk lebih menyadari pentingnya kedisiplinan dalam belajar agar dapat mencapai keberhasilan yang diinginkannya, serta memberikan bantuan kepada sekolah untuk lebih memahami dan menambah pengetahuan dalam upaya meningkatkan prestasi belajar siswa dan juga kedisiplinan siswa.

\section{METODE PENELITIAN}


Populasi yang ada pada penelitian ini adalah siswa SMA kelas XI dan XII Perguruan Setia Budi Abadi Perbaungan yang berjumlah 189 orang. Metode pengambilan sampel yang digunakan adalah proportionate stratified random sampling, yaitu suatu teknik dalam pengambilan sampel yang dilakukan apabila sifat atau unsur dalam populasi tidak homogen dan berstrata secara proporsional (Sugiyono, 2010). Jumlah sampel yang akan dipakai dalam penelitian ini adalah 123 orang siswa kelas XI dan XII Perguruan Setia Budi Abadi Perbaungan.

Alat pengumpulan data yang digunakan pada penelitian ini adalah dengan menggunakan metode dokumentasi untuk mengukur prestasi belajar dan metode pembagian skala untuk mengukur kedisiplinan. Metode dokumentasi adalah teknik dalam mengumpulkan data penelitian mengenai variabel atau hal-hal yang berupa transkrip, catatan, buku, surat, koran, prasasti,majalah, notulen rapat, leger nilai, agenda, dan lain-lain. Metode dokumentasi merupakan sumber data yang berupa benda-benda mati sehingga tidak mudah berubah atau mudah bergerak (Dimyati, 2013). Dalam penelitian ini, prestasi belajar siswa diukur dengan menggunakan metode dokumentasi dari nilai yang telah didapat oleh siswa pada rapor sekolah. Semakin tinggi nilai yang diperoleh menunjukkan bahwa siswa tersebut memiliki prestasi belajar yang tinggi, begitu juga sebaliknya semakin rendah nilai yang diperoleh menunjukkan bahwa siswa tersebut memiliki prestasi belajar yang rendah.

Jenis skala yang digunakan adalah skala Likert. Dengan skala Likert, maka variabel yang akan diukur dijabarkan menjadi suatu indikator variabel yang kemudian indikator atau komponen-komponen tersebut dijadikan titik tolak dalam menyusun aitem-aitem instrument yang berupa pertanyaan atau pernyataan (Sugiyono, 2010). Skala yang digunakan dalam penelitian ini menggunakan empat alternatif jawaban yaitu SS (sangat sesuai), S (sesuai), TS (tidak sesuai), dan STS (sangat tidak sesuai), yang mana pernyataan favourable maka mengandung nilai-nilai yang positif, SS (sangat sesuai) diberikan bobot 4 (empat), S (sesuai) dengan bobot 3 (tiga), TS (tidak sesuai) dengan bobot 2 (dua), dan STS (sangat tidak sesuai) dengan bobot 1 (satu). Sistem penilaian sebaliknya, jika pernyataan unfavourable yaitu SS (sangat sesuai) diberikan bobot 1 (satu), S (sesuai) dengan bobot 2 (dua), TS (tidak sesuai) dengan bobot 3 (tiga), dan STS (sangat tidak sesuai) dengan bobot 4 (empat). 
Skala kedisiplinan disusun berdasarkan teori yang dikembangkan oleh Atmosudirdjo (dalam Offirstson, 2014), yang terdiri dari 3 (tiga) aspek, yaitu (1) Suatu sikap mental (mental attitude, state of mind; (2) Suatu pengetahuan (knowledge) tentang aturan-aturan dalam perilaku, sistem atau norma-norma; (3) Suatu sikap kelakuan (behavior) yang menunjukkan pengertian dan kesadaran, kesungguhan hati dalam mentaati segala hal secara cermat dan tertib.

Pelaksanaan uji validitas dan reliabiltas alat ukur dilakukan pada siswa SMA Methodist Tanjung Morawa. Sebanyak 102 siswa SMA Methodist Tanjung Morawa menjadi sampel. Pada skala kedisiplinan, hasil uji coba alat ukur menunjukkan bahwa 38 dari 48 aitem dinyatakan sahih. Uji validitas dalam tryout penelitian ini menggunakan metode corrected item total correlation dimana aitem yang valid dapat dilihat pada tabel corrected item total correlation berdasarkan $r$ minimal 0,3 dengan nilai $r$ bergerak dari 0,314-0,658. Dalam skala kedisiplinan ini diperoleh reliabilitas Alpha Cronbach sebesar 0,919 . Dengan hasil ini diperoleh arti bahwa skala ini layak digunakan sebagai alat pengumpulan data dalam penelitian ini.

\section{HASIL DAN PEMBAHASAN}

\section{Analisa Deskriptif Prestasi Belajar dan Kedisiplinan}

Tabel 1. Statistik Deskriptif

\begin{tabular}{lccc}
\hline \multicolumn{4}{c}{ Descriptive Statistics } \\
\hline & $\boldsymbol{N}$ & Mean & Std. Deviation \\
Prestasi Belajar & 123 & 2118,41 & 93,565 \\
Kedisiplinan & 123 & 125,14 & 12,901 \\
\hline
\end{tabular}

Tabel 1 merupakan statistik deskriptif variabel prestasi belajar dan kedisiplinan. Tabel ini menunjukkan variabel prestasi belajar memiliki nilai rata-rata 2118,41 dengan standar deviasi 93,565. Sedangkan pada variabel kedisiplinan memiliki nilai rata-rata 125,14 dengan standar deviasi 12,901.

Tabel 2. Kriteria Tingkat Prestasi Belajar dan Kedisiplinan

$\begin{array}{lllll}\text { Variabel } & \text { Rentang Nilai } & \text { Kategori } & \text { Jumlah (n) } & \text { Persentase }\end{array}$


Vol 2, No. 1, Agustus 2019: 24 - 35, DOI: 10.34007/jehss.v2i1.48

\begin{tabular}{|c|c|c|c|c|}
\hline \multirow[t]{4}{*}{ Prestasi Belajar } & $x<2059$ & Rendah & 36 & $29,27 \%$ \\
\hline & $2059 \leq x<2165$ & Sedang & 33 & $26,83 \%$ \\
\hline & $x \geq 2165$ & Tinggi & 54 & $43,90 \%$ \\
\hline & Jumlah & & 123 & $100 \%$ \\
\hline \multirow[t]{4}{*}{ Kedisiplinan } & $x<76$ & Rendah & 0 & $0 \%$ \\
\hline & $76 \leq x<110$ & Sedang & 10 & $8,1 \%$ \\
\hline & $x \geq 110$ & Tinggi & 113 & $91,9 \%$ \\
\hline & Jumlah & & 123 & $100 \%$ \\
\hline
\end{tabular}

Tabel 2 merupakan kriteria tingkat prestasi belajar dan kedisiplinan. Tabel ini menunjukkan rata-rata prestasi belajar berada pada kategori tinggi dengan presentase sebesar 36,59\%. Sedangkan rata-rata kedisiplinan berada pada kategori tinggi dengan presentase sebesar $91,9 \%$.

Penelitian ini adalah penelitian korelasional yang digunakan untuk mengetahui ada atau tidaknya korelasi antara kedisiplinan dengan prestasi belajar. Namun sebelum dilakukan uji korelasi, peneliti akan terlebih dahulu melakukan uji asumsi untuk menentukan jenis statistikyang akan digunakan untuk uji korelasi, yaitu parametik atau non-parametik.

Uji normalitas dilakukan agar dapat mengetahui apakah setiap data variabel penelitian telah menyebar secara normal atau tidak. Uji normalitas sebaran dalam penelitian ini diuji dengan menggunakan uji Kolmogorov Smirnov Test. Data dikatakan berdistribusi normal jika $\mathrm{p}<0,05$ (Priyatno, 2010). Uji normalitas pada variabel prestasi belajar diperoleh koefisien KS-Z = 1,769 dengan Sig sebesar 0,004 untuk uji 2 (dua) arah (two tailed) dan sedangkan penelitian ini memiliki hipotesis satu arah, sehingga yang dipakai adalah uji 1 (satu) arah (one tailed) sebesar 0,002 ( $\mathrm{p}<0,05)$, yang memiliki arti bahwa data pada variabel prestasi belajar memiliki sebaran atau berdistribusi tidak normal. Uji normalitas yang dilakukan terhadap variabel kedisiplinan diperoleh koefisien KS-Z = 0,724 dengan Sig sebesar 0,671 untuk uji 2 (dua) arah (two tailed) dan sedangkan penelitian ini memiliki hipotesis satu arah, sehingga yang dipakai adalah uji 1 (satu) arah (one tailed) sebesar 0,3355 ( $\mathrm{p}>0,05$ ), yang memiliki arti bahwa data pada variabel kedisiplinan memiliki sebaran atau berdistribusi normal.

Tabel 3. Hasil Uji Normalitas

\begin{tabular}{|c|c|c|c|c|c|c|}
\hline Variabel & SD & KS-Z & Sig. & $\mathbf{P}$ & Keterangan & \\
\hline Prestasi Belajar & 93,565 & 1,769 & 0,002 & $\mathrm{p}<0,05$ & Sebaran tidak normal & \\
\hline Wwit http://mahes & e.web.i & $2 /$ inde & /jehss & $\omega \mathrm{m}$ & institut@gmail.com & 31 \\
\hline
\end{tabular}




$\begin{array}{llllll}\text { Kedisiplinan } & 12,901 & 0,724 & 0,3355 & p>0,05 & \text { Sebaran normal }\end{array}$

Dari hasil uji normalitas data, didapat hasil data berdistribusi tidak normal pada salah satu variabel, jadi uji korelasi yang digunakan dalam penelitian ini adalah korelasi Spearman rho. Berdasarkan hasil analisis korelasi antara kedisiplinan dengan prestasi belajar, diperoleh koefisien korelasi Spearman rho sebesar 0,688 dengan sig sebesar $0,000(\mathrm{p}<0,05)$. Hasil tersebut menunjukkan bahwa terdapat hubungan positif antara kedisiplinan dengan prestasi belajar. Dari hasil perhitungan tersebut, maka hipotesis yang diajukan dalam penelitian ini menunjukkan adanya hubungan positif antara kedisiplinan dan prestasi belajar diterima.

\section{Hubungan Kedisiplinan dengan Prestasi Belajar}

Hasil penelitian pada 123 siswa SMA Setia Budi Abadi Perbaungan yang menjadi partisipan peneliti diperoleh bahwa ada hubungan positif antara prestasi belajar dengan kedisiplinan dengan koefisien korelasi spearman rho sebesar $r=0,688$ dan $\mathrm{p}$ sebesar 0,000, artinya semakin tinggi kedisiplinan yang dimiliki oleh individu maka prestasi belajar juga semakin tinggi, dan sebaliknya semakin rendah kedisiplinan maka semakin rendah prestasi belajar.

Hasil penelitian yang menyatakan adanya hubungan antara kedisiplinan dengan prestasi belajar sejalan dengan pendapat Sumantri (2010) yang menunjukkan adanya hubungan antara kedisiplinan dengan prestasi belajar. Disiplin belajar memiliki pengaruh yang signifikan terhadap prestasi belajar, selain faktor-faktor lain yang mempengaruhi prestasi belajar, maka dengan disiplin dalam belajar dengan menyusun rencana atau schedule yang berupa jadwal yang mesti ditaati sendiri, tentu akan menjadi kebiasaan yang menyatu dalam cara-cara belajar.

Penelitian prestasi belajar pada siswa SMA Setia Budi Abadi Perbaungan yang masuk dalam kategori tinggi sebanyak 54 orang dengan persentase 43,90 persen, kemudian 33 siswa yang prestasi belajarnya dikategorikan sedang dengan persentase sebesar 26,83 persen, sedangkan siswa yang prestasi belajarnya rendah berjumlah 36 orang dengan persentase 29,27 persen. Berdasarkan penjelasan di atas dapat disimpulkan rata-rata siswa SMA Setia Budi Abadi Perbaungan prestasi belajarnya dikategorikan tinggi. 
Berdasarkan hasil wawancara terhadap beberapa siswa yang termasuk kedalam kategori prestasi belajar rendah dengan presentase 29,27 persen, terlihat dari mereka yang hanya belajar di sekolah dan tidak mengikuti les private karena mereka merasa hal tersebut tidak diperlukan. Pada saat pulang sekolah, mereka akan berkumpul dengan teman-teman yang lain untuk bermain. Pada saat akan diadakannya ulangan, sebagian dari mereka mengaku tidak belajar karena malas.

Siswa yang termasuk dalam kategori prestasi belajar sedang sebanyak 26,83 persen. Hal ini dapat ditunjukkan dari hasil wawancara yang menyatakan bahwa sebagian dari mereka mengikuti les private setelah sekolah. Mereka juga mengatakan mereka selalu belajar sehari sebelum ujian. Siswa yang prestasi belajarnya termasuk dalam kategori tinggi sebanyak 43,90 persen mengaku mereka memiliki keyakinan bahwa mereka dapat menjadi orang sukses kedepannya apabila pada saat sekolah mereka belajar dengan sungguh-sungguh. Sebagian dari mereka juga mengatakan bahwa mereka merasa malu apabila mendapatkan nilai yang rendah.

Penelitian kedisiplinan pada siswa SMA Setia Budi Abadi Perbaungan yang termasuk dalam kategori tinggi sebanyak 113 orang dengan persentase 91,9 persen, kemudian 10 siswa dikategorikan kedisiplinannya sedang dengan persentase sebesar 8,1 persen, sedangkan siswa yang kedisiplinannya rendah tidak ada. Berdasarkan penjelasan di atas dapat disimpulkan rata-rata siswa SMA Setia Budi Abadi dikategorikan tinggi. Berdasarkan hasil penelitian menunjukkan bahwa tidak ada siswa yang termasuk kategori kedisiplinan rendah. Hal ini dikarenakan siswa-siswa mengaku bahwa mereka merasa segan apabila tidak menuruti perintah yang diajukan oleh guru. Guru-guru di sekolah tersebut sangat peduli terhadap siswanya.

Siswa yang termasuk kategori kedisiplinan sedang sebanyak 8,1 persen. Hal ini ditunjukkan dari hasil wawancara dengan beberapa siswa menyatakan kadang mereka merasa bosan apabila harus selalu mengikuti setiap peraturan yang ada di sekolah. Mereka mengungkapkan bahwa mereka ingin memiliki pengalaman yang menyenangkan pada saat sekolah, sehingga terkadang mereka melanggar beberapa peraturan yang ada di sekolah tersebut. Perilaku di atas berkenaan dengan salah satu aspek kedisiplinan, yaitu mematuhi peraturan dan norma yang berlaku.

Siswa yang termasuk kategori kedisiplinan tinggi sebanyak 91,9 persen. Hal ini ditunjukkan dari hasil wawancara kepada beberapa siswa yang menyatakan bahwa 
mereka harus bisa melakukan setiap hal yang sudah direncanakan dari awal. Guru-guru di sekolah tersebut juga selalu mengatakan kepada siswa-siswi bahwa kedisiplinan sangat penting untuk diterapkan sejak dini, karena kedisiplinan dapat menjadi suatu acuan untuk menjadi orang yang sukses di masa depan. Perilaku di atas berkenaan dengan aspek kedisiplinan, yaitu ketepatan dan mengerjakan pekerjaan dengan baik.

Berdasarkan penjelasan di atas maka dapat dikatakan jika seseorang memiliki kesadaran untuk lebih disiplin dalam melakukan segala hal dan patuh terhadap peraturan yang diberlakukan, maka mereka akan mendapatkan hal yang mereka inginkan. Dengan demikian, kesimpulan yang dapat ditarik dalam penelitian ini adalah ada hubungan positif antara kedisiplinan dengan prestasi belajar, yang artinya semakin tinggi kedisiplinan siswa, maka semakin tinggi pula prestasi belajar yang dapat dicapai. Sebaliknya semakin rendah kedisiplinan siswa, maka semakin rendah prestasi belajar yang dapat dicapai.

\section{SIMPULAN}

Terdapat hubungan yang positif antara kedisiplinan dan prestasi belajar pada siswa SMA kelas XI dan XII Perguruan Setia Budi Abadi Perbaungan. Hal ini dibuktikan dengan nilai koefisien korelasi Spearman rho (r) sebesar 0,688 dengan p sebesar 0,000 (p < 0,05), yang artinya apabila semakin tinggi kedisiplinan maka prestasi belajar semakin tinggi, dan sebaliknya apabila semakin rendah kedisiplinan maka prestasi belajar juga akan semakin rendah.

\section{DAFTAR PUSTAKA}

Dimyati, J. (2013). Metodologi Penelitian Pendidikan dan Aplikasinya pada Pendidikan Anak Usia Dini (PAUD). Jakarta: PT. Fajar Interpratama Mandiri.

Habsari, S. (2005). Bimbingan dan Konseling SMA untuk Kelas X. Bandung: Grafindo Media Pratama.

Habsari, S. (2005). Bimbingan dan Konseling SMA untuk Kelas XI. Bandung: Grafindo Media Pratama.

Hurlock, E.B. (2006). Perkembangan Anak. Jakarta: Erlangga.

Jihad, A \& Haris, A. (2013). Evaluasi Pembelajaran. Yogyakarta: Multi Pressindo.

Kusuma, Z.L. dan Subkhan. (2015). Pengaruh Motivasi Belajar dan Kedisiplinan Belajar terhadap Prestasi Belajar Mata Pelajaran Akuntansi Siswa Kelas XI IPS SMA N 3 Pati Tahun Pelajaran 2013/2014. Economic Education Analysis Journal. 4 (1): 164-171

Liauwrencia, P.F. \& Putra, D. (2014). Hubungan Antara Konsep Diri dengan Prestasi Belajar Siswa Kelas XII IPA2 Tahun Ajaran 2013/2014 di SMA Dharma Putra Tangerang. Jurnal NOETIC Psychology. 4 (1): 62-80

Offirstson, T. (2014). Mutu Pendidikan Madrasah Tsanawiyah. Yogyakata: Deepublish.

Priyatno, D. (2010). Teknik Mudah dan Cepat Melakukan Analisis Data Penelitian dengan SPSS. Yogyakarta : Gaya Media 
Puspitasari, H.M. dan Sutriyono. (2017). Hubungan Kemandirian Belajar dan Kedisiplinan Belajar terhadap Prestasi Belajar Matematika. Jurnal Mitra Pendidikan. 1 (10): 1007-1020

Rusmiati. (2017). Pengaruh Minat Belajar terhadap Prestasi Belajar Bidang Studi Ekonomi Siswa MA Al Fattah Sumbermulyo. UTILITY: Jurnal Ilmiah Pendidikan dan Ekonomi. 1 (1): 21-36

Seran, S. (2016). Pendidikan dan Pertumbuhan Ekonomi versus Kemiskinan Penduduk (Kasus Provinsi Nusa Tenggara Timur). Yogyakarta: Deepublish.

Sugiyono. (2010). Metode Penelitian Pendidikan. Bandung: Alfabeta.

Sumantri, B. (2010). Pengaruh Disiplin Belajar terhadap Prestasi Belajar Siswa Kelas XI SMK PGRI 4 Ngawi Tahun Pelajaran 2009/2010. Jurnal Media Prestasi. 6 (3): 117-131

Syah, M. (2015). Psikologi Belajar. Jakarta: Rajawali Pers.

Tilaar, H.A.R. (2002). Perubahan Sosial dan Pendidikan. Jakarta: PT. Gramedia Widiasmara Indonesia.

Triwiyanto, T. (2015). Pengantar Pendidikan. Jakarta: Bumi Aksara. 